\title{
STUDY ON THE IMPACT OF REVERSE LOGISTICS IN THE TRANSPORTATION SECTOR
}

\author{
Dr. J. Rengamani \\ Associate Professor, AMET Business School, AMET University, India \\ V. Venkatraman \\ Research Scholar, AMET University, India
}

\begin{abstract}
Reverse Logistics demands a different perspective on the role of supply and how it should be managed. When it is considered the mirror image of logistics and afforded top management attention, the supply area can have a substantial bottom-line impact with savings in the five to thirty percent range. Translated into profits, a five percent savings in supply dollars may increase profits between thirty and fifty percent. Leenders and Blenkhorn document the innovative efforts of major American and Foreign firms in both the public and private sector which have tested the reverse logistics concept and found that it is essential for quality control, MRP, JIT, global demands, and keeping the competitive edge. This study examines the reverse logistics perspective and its application in the logistics arena.
\end{abstract}

Key words: Supplier, Purchaser, Relationship Logistics.

Cite this Article: Dr. J. Rengamani and V. Venkatraman, Study on The Impact of Reverse Logistics In The Transportation Sector. International Journal of Design and Manufacturing Technology 6(2), 2015, pp. 30-37.

https://iaeme.com/Home/issue/IJDMT?Volume $=6 \&$ Issue $=2$

\section{INTRODUCTION}

Reverse Logistics is the process of planning, implementing, and controlling the efficient, cost effective flow of raw materials, in-process inventory, finished goods and related information from the point of consumption to the point of origin for the purpose of recapturing value or proper disposal. More precisely, reverse logistics is the process of moving goods from their typical final destination for the purpose of capturing value, or proper disposal. Remanufacturing and refurbishing activities also may be included in the definition of reverse logistics. Reverse logistics is more than reusing containers and recycling packaging materials. 
The dramatically changing market conditions have made many firms to realise the requirement of significant changes in their purchasing function. In firms, purchasing has become proactive and strategically important. This phenomenon has been referred to as 'Reverse Logistics'. As the term implies, there are clear similarities with the logistics concept. During the last four decades, many technology and sales-oriented companies have transformed themselves into competitive customer driven organisations. Pressured to meet the demands of global competition, today's buyers and sellers must utilise effective strategies to produce quality products while cutting costs. The reverse logistics is the innovative strategy of supply management. This breakthrough strategy reverses the traditional supplier-buyer relationship in that the buyer aggressively and selectively seeks a long-term relationship with a few key suppliers to maximise quality and minimise costs. The organizations in a variety of industries can put reverse logistics strategies to work for them. Leenders and Blenkhorn illustrate "important decision-making factors such as: when to consider using a small or large supplier; how to turn social, environmental and political mandates -- minority contracts -- into a profitable advantage; and how to take new technological needs to the right supplier for the best deal, best service, and highest quality products". Reverse Logistics will focus management attention on establishing an acquisition strategy which is more concerned with supplier development (and in many instances, the development of non-suppliers into highly valued suppliers). Reverse logistics is the concept of logistics in which the customer seeks the firm rather than marketers seeking the customer. Usually, this is done through traditional means of advertising, such as television advertisements, print magazine advertisements and online media. Reverse logistics works mainly on the basis of the Law of Attraction. While logistics mainly deals with finding the right set of customers and targeting them, Reverse logistics deals with strategies that would make the customer find the company offering the product.

\section{REVERSE LOGISTICS}

In the logistics current scenario, the buyer-supplier relationship has changed considerably. The traditional relationship, where the seller takes the initiative by offering a product, is increasingly being replaced by one where the buyer actively searches for a supplier who is able to fulfil its exact needs. The phenomenon where the supplier is subsequently urged to deliver the product with the required specifications and where the buyer participates in identifying the best solution is called Reverse Logistics. Graphically, Reverse Logistics can be represented as in Chart-1:



\section{The Purchaser tries to persuade the Supplier to supply}

\section{Chart-1Reverse Logistics}

The simple reversal of arrows in Chart-1 produces a substantially different perspective. The purchaser, instead of being persuaded to buy, now tries to persuade the supplier to provide! 


\section{REASONS FOR REVERSE LOGISTICS}

Reverse Logistics is not a technique, but a changed perspective on purchasing and supply management, and is found to lead to cost reductions of 5 to 30 percent. In addition, reverse logistics may result in improved product quality, delivery performance and service support. The traditional purchaser and the reverse logistics oriented person can be regarded as two extremes, each with their own characteristics. The characteristics of the reverse logistics oriented purchaser have far-reaching implications for suppliers. A supplier needs to assess the purchaser with whom he wants to do business and translate this into a strategy and action. One direct consequence for the supplier is an increasing attention to the use of relationship management, which may lead to the implementation of account management.

Reverse Logistics is a powerful method to increase the sales by 'reversing' many of the conventional logistics procedures that really aren't very productive. It can be summarised as follows

- The seller can sell a lot more of the products or services by using methods that get prospects to approach the seller instead of the seller seeking them out. Converting these warm prospects to paying customers is a breeze compared to convincing the cold prospects.

- A system of multiple contacts to qualified prospects can reduce the seller's expenses dramatically and increase the profits.

- The real money in any business is in repeat sales to customers who already know the seller. This type of logistics is easily 10 times as profitable as selling to new customers.

Using reverse logistics, buyers can create "good, better and exceptional suppliers" overtime.

Reverse logistics works by not using hard sale tactics. In some cases reverse logistics means no salesmanship at all. Instead, reverse logistics allows consumers needing your product to come to you by showing them that you are concerned about what they need and that you are savvy enough to help them meet their needs. Instead of advertising your business and trying to convince people that your product or service is better than the competitors you offer them helpful information in solving their problem or need. This way you are giving the consumer practical advice they are looking for at no price. Then at the end of your advice you include a little information about yourself including your website. Since you have talked about their specific issue and using an answer to their query, the consumer does not feel as though you are trying to sell them anything. Those that decide your product or service is for them will then click on your link to see what you have to offer and since you were the one that offered them helpful advise they will be more tempted to buy from you. Reverse logistics works simply because you are helping the consumer achieve a goal they themselves have without trying to force them to buy anything. The consumer comes to you, not you to them.

\section{AN EXAMPLE OF REVERSE LOGISTICS}

The most commonly talked about example must be of the cosmetics company 'Dove'. Now cosmetics companies usually talk about how their products will add to your flawed looks. If you're dark, they'll make you fair. If you're pimply, they'll clear it up. If your skin is dry, they'll moisten it. And so on. Cosmetic companies tend to pick and criticize your looks and create this impression that you're quite ugly overall, and the only way 
to make yourself more desirable is to use their products. As if their products actually make a beauty of a beast.

But Dove chose a different path altogether. Instead of pointing at the little flaws which your skin might have, Dove asked women to come together and celebrate their beauty. You will now notice, how very less coercive Dove ads seem as compared to the ads of other cosmetics brands. It's a completely different, novel approach to logistics altogether. Dove rarely uses models, who are viewed as plastic and artificial. Dove uses 'real women', beautiful, but not extremely so, to add a touch of realism to the ad. And it is this appeal, the seeming genuineness of women, the lack of coercion, and the lack of this artificially created sense of inferiority of women to the models in terms of looks, that drew more and more women towards using the products of Dove. And yes, it has been successful.

The example probably told us a bit about what reverse logistics strategies are. It is a sort of assertion to the people that they don't really need to use the products of a particular company. It is sort of like reverse psychology-which loosely means that you get people to do something by asking them not to. Of course, it doesn't forbid the people from using their products or any such thing, but reverse logistics tells people that they're awesome overall even without using any of the artificial add-ons which they sell.

It may seem illogical that this approach should work. On one hand companies practicing reverse logistics seem to be telling you not to use their products, and on the other hand, we see people going out and buying them. So what is reverse logistics's whole appeal?

\section{WHY REVERSE LOGISTICS WORKS?}

Reverse logistics has seen quite a few success stories, even with its fairly unusual approach. This is because it is a breath of fresh air from the otherwise fear-inducing advertising techniques. How many times have you gone and purchased something because its advertising campaign had some thinly veiled gory eventuality, should you not use the product? It's happened almost too many times. Let us continue the example of cosmetics. How many of those wrinkle-reducing products ads show women frowned upon just because age is catching up with them. The ad runs as, "see what happened to this lady who didn't use the wrinkle reducing cream when she should have? Now she's old, ugly and no one likes her. You want to be this way?". People started seeing this approach as an open threat and didn't like it. No one wants to be told what to do. And this is where reverse logistics has been successful. Don't tell people what to do. It appeals to the people's sensibilities; the result of this is that people warm up to these products. They want to use a product that doesn't poke fun at them, or threatens them. They want one which makes them feel good about themselves, doesn't brag and yes, is effective. Of course, there are some important caveats to using these tips. Of course, a new entrant in a market ought not to try this. Dove and other reverse marketers have been successful because they are already established brands and people know how good they are. Secondly, the products have to be so good that they speak for themselves!

\section{REVERSE LOGISTICS ORIENTED PURCHASING}

Reverse logistics approach to purchasing obviously requires other capabilities than traditional purchasing does. As with every significant organisational change, the successful implementation of a reverse logistics strategy requires

- personnel with the right education and attitude

- sufficient commitment and support from the organisation and 
- Practical guidelines that show reverse logistics oriented purchasers how to implement such a strategy.

Organisational commitment and support should be fostered by top management and can be demonstrated by elevating purchasing position in the organisation and involving it formally in various critical strategic decision making processes.

\section{GROWTH OF REVERSE LOGISTICS}

Reverse logistics is where the customer becomes the marketer. Social media is an example of reverse logistics. Customers are logistics to other customers and to organizations. That's the big differentiator between social media and traditional media, where the organization markets and communicates at the customer.

Search is an example of reverse logistics. A typical search is an advertisement. A search for "cheap flights Dublin" asks organizations to respond to my specific request for a good value flight to Dublin. The more clever the organization, the more specific their response will be.

Reviews are a great example of reverse logistics. The best reviews are authentic. They are by real people writing about things they really care about. In reverse logistics the marketer needs to behave as if they are the customer of the customer. What is the perfect customer? They enthusiastically watch ads and read logistics material. They respond quickly and buy lots. They tell their friends to buy lots. They are loyal.

How can a marketer or communicator become the perfect customer? Enthusiastically read up on and understand the customer. Watch them as they search, navigate and interact on social media. Think carefully about the message they are sending out and respond specifically to that message. Respond quickly and spend effort to make sure they are happy.

What's the worst customer? They totally ignore your ads. Or else they blatantly misunderstand and deride them. They tell lies and half-truths about you. They hate you and enthusiastically tell their friends never to buy from you. They publish lots of negative stuff about you and are happy when they see you fail.

Reverse logistics is about letting go control. It is about being highly adaptive and responsive. It is about allowing the customer to become the organization, so that the organization becomes the customer. It is about being loyal to the customer. It is about listening. It is about being useful.

\section{CONCLUSION}

Reverse logistics is not a technique, but a changed perspective on purchasing and supply management, and is found to lead to substantial material cost reductions. In addition, reverse logistics may result in improved product quality, delivery performance, and service support. The traditional buyer and the reverse logistics oriented purchasing professional can be regarded as two extremes, each with his or her own characteristics. The characteristics of the reverse logistics oriented purchaser have far-reaching implications for suppliers. A supplier needs to assess the purchasers with whom it wants to do business and translate this assessment into a long-term strategy.

Reverse Logistics is an aggressive and imaginative approach that requires a strategic perspective of the supply role in the organisation. In reverse logistics, the purchaser takes the initiative rather than the supplier. Reverse logistics may involve the current, past, or new suppliers for any kind of products both existing and new. So, both 
public and private organisations can use reverse logistics to increase supply effectiveness.

\section{REFERENCES}

[1] Bandyopadhyay, S. (2004), Interfirm influence strategies within distribution channels in theemerging Indian market. Advances in Competitiveness Research. Vol. 12, Iss. 1, pp. 1-9.

[2] Barbara B. Jackson, "Building Customer Relationships That Last," Harvard Business Review, November-December 1985.

[3] Beekman, A., \& Robinson, R. (2004), Supplier partnership and the small, high - growth firm: selecting for success. Journal of Small Business Management, Vol. 42, Issue. 1, pp. 59-77. https://doi.org/10.1111/j. 1540-627X.2004.00097.x

[4] Benton, W.C., \& Maloni, M.(2005), The influence of power driven buyer/seller relationships on supply chain satisfaction. Journal of Operations Management.

[5] Briscoe, J., Fawcett, S., \& Todd, R. (2005). The implementation and impact of ISO 9000 among small manufacturing enterprises. Journal of Small Business Management.

[6] Christiansen, P.E., \& Maltz, A.(2002). Becoming an "interesting" customer: procurement strategies for buyers without leverage. International Journal of Logistics: Research and Applications.

[7] David L Blenkhorn and Peter M. Banting, "How Reverse Logistics Changes Buyer-Seller Roles," Industrial Logistics Management, vol. 20 (1991).

[8] David N. Burt, "Managing Suppliers Up to Speed," Harvard Business Review, July-August 1989.

[9] Ellegaard, C., \& Ritter, T. (2006, September). Customer Attraction and its Purchasing Potential. Paper presented at the 22nd IMP Conference, Milan.

[10] Ellegaard,C., Johansen, J., \& Drejer, A. (2003). Managing industrial buyer - supplier relations - the case for attractiveness. Integrated Manufacturing Systems.

[11] Gait J.D.A. and B.G. Dale, "Supplier Development: A British Study," International Journal of Purchasing and Materials Management, 27, 1 (1991).

[12] Ghijsen, P.W.T., Semeijn, J., \& Ernstson, S. (2010). Supplier satisfaction and commitment: The role of influence strategies and supplier development, Journal of Purchasing \& Supply Management.

[13] Hahn C.K. , C.A. Watts, and K.Y. Kim, "Supplier Development Program: A Conceptual Model," Journal of Purchasing and Materials Management, 26, 2 (1990). 
[14] Harris, L.C., O’Malley, L., Patterson, M. (2003), Professional interaction: Exploring the concept of attraction. Logistics theory.

[15] Helm, S., Rolfes,L., \& Günter, B. (2006). Suppliers' willingness to end unprofitable customer relationships: an exploratory investigation in the German mechanical engineering sector. European Journal of Logistics.

[16] Henseler,J., Ringle, C. M., \& Sikovics, R. (2009). The use of partial least square path modeling in international logistics. Advances in International Logistics.

[17] James C. Anderson and James A. Narus, "Partnering as a Focused Market Strategy," California Management Review, Spring 1991;

[18] Johnsen,T.E. (2009). Supplier involvement in new product development and innovation: taking stock and looking to the future. Journal of Purchasing \& Supply Management.

[19] Krause D.R. "Supplier Development: Current Practices and Outcomes," International Journal of Purchasing and Materials Management, 33, 2 (1997).

[20] Michiel R. Leenders and David L. Blenkhorn, Reverse Logistics: The New Buyer-Supplier Relationship, (New York: The Free Press, 1988).

[21] Morrisey, J., \& Pittaway, L. (2006). Buyer - supplier relationships in small firms; the use of social factors to manage relationships, International Small Business Journal

[22] Mortensen, M.H., Freytag, P. V., \& Arlbjørn, J. S. (2008). Attractiveness in supply chains: A process and matureness perspective. International Journal of Physical Distribution and Logistics Management.

[23] Nyaga,G.N., Whipple, J. M., Lynch, D. F. (2010). Examining supply chain relationships: Do buyer and supplier perspectives on collaborative relationships differ?. Journal of Operations Management.

[24] Ramsay, J., \& Wagner, B. A. (2009). Organisational Supplying Behaviour: Understanding supplier needs, wants and preferences. Journal of Purchasing \& Supply Management.

[25] Rowland T. Moriarty and Thomas J. Kosnik, "High-Tech Logistics: Concepts, Continuity, and Change," Sloan Management Review, Summer 1989.

[26] Sang-Lin Han, David T. Wilson, and Shirish P. Dant, "Buyer-Supplier Relationships Today," Industrial Logistics Management, vol. 22 (1993).

[27] Schumacher, S. C., Schiele, H., Contzen, M., \& Zachau, T. (2008). Die 3 Faktoren desEinkaufs: Einkauf und Lieferanten strategisch positionieren. Weinheim: Wiley - VCH. 
Study on The Impact of Reverse Logistics In The Transportation Sector

[28] Thomas V. Bonoma, "Major Sales: Who Really Does the Buying?" Harvard Business Review, May-June 1982.

[29] Wagner, S.M. (2006). Supplier development practices: an exploratory study. European Journal of Logistics.

[30] Watts C.A. and C.K. Hahn, "Supplier Development Programs: An Empirical Analysis," International Journal of Purchasing and Materials Management, 29, 2 (1993).

[31] Wognum,P., Fisscher, O. A., \& Weenink, S.A. (2002). Balanced relationships: management of client - supplier relationships in product development. Technovation.

[32] Wynstra,F., Weggeman, M., \& van Weele, A. (2003). Exploring purchasing integration in product development. Industrial Logistics Management.

[33] Zsidisin,G.A., \& Smith, M. E. (2005). Managing supply risk with early supplier involvement: a case study and research propositions. The Journal of Supply Chain Management. 